\title{
Article \\ Antibiotic Use in Alpine Dairy Farms and Its Relation to Biosecurity and Animal Welfare
}

\author{
Francesca Menegon (), Katia Capello, Jacopo Tarakdjian (), Dario Pasqualin, Giovanni Cunial, Sara Andreatta, \\ Debora Dellamaria, Grazia Manca, Giovanni Farina and Guido Di Martino *(i)
}

check for

updates

Citation: Menegon, F.; Capello, K.; Tarakdjian, J.; Pasqualin, D.;

Cunial, G.; Andreatta, S.;

Dellamaria, D.; Manca, G.; Farina, G.; Di Martino, G. Antibiotic Use in Alpine Dairy Farms and Its Relation to Biosecurity and Animal Welfare. Antibiotics 2022, 11, 231. https:// doi.org/10.3390/antibiotics11020231

Academic Editor: Diane

Ashiru-Oredope

Received: 10 January 2022

Accepted: 8 February 2022

Published: 10 February 2022

Publisher's Note: MDPI stays neutral with regard to jurisdictional claims in published maps and institutional affiliations.

Copyright: (c) 2022 by the authors. Licensee MDPI, Basel, Switzerland. This article is an open access article distributed under the terms and conditions of the Creative Commons Attribution (CC BY) license (https:/ / creativecommons.org/licenses/by/ $4.0 /)$.
Istituto Zooprofilattico Sperimentale delle Venezie, Viale dell'Università 10, 35020 Legnaro, Italy; fmenegon@izsvenezie.it (F.M.); kcapello@izsvenezie.it (K.C.); jtarakdjian@izsvenezie.it (J.T.); dpasqualin@izsvenezie.it (D.P.); gcunial@izsvenezie.it (G.C.); sandreatta@izsvenezie.it (S.A.); ddellamaria@izsvenezie.it (D.D.); gmanca@izsvenezie.it (G.M.); gfarina@izsvenezie.it (G.F.)

* Correspondence: gdimartino@izsvenezie.it

\begin{abstract}
The quantification of antimicrobial usage (AMU) in food-producing animals can help identify AMU risk factors, thereby enhancing appropriate stewardship policies and strategies for a more rational use. AMU in a sample of 34 farms in the Province of Trento (north-eastern Italy) from 2018 to 2020 was expressed as defined daily doses for animals per population correction unit according to European Surveillance of Veterinary Antimicrobial Consumption guidelines (DDDvet) and according to Italian guidelines (DDDAit). A retrospective analysis was carried out to test the effects of several husbandry practices on AMU. Overall, the average AMU ranged between 6.5 DDDAit in 2018 and 5.2 DDDAit in 2020 (corresponding to 9 and 7 DDDvet, respectively), showing a significant trend of decrement $(-21.3 \%)$. Usage of the highest priority critically important antimicrobials (HPCIA) was reduced by 83\% from 2018 to 2020. Quarantine management, available space, water supply, animals' cleanliness and somatic cell count had no significant association with AMU. Rather, farms with straw-bedded cubicles had lower AMU levels than those with mattresses and concrete floors $(p<0.05)$. In conclusion, this study evidenced a decrement in AMU, particularly regarding HPCIA, but only a few risk factors due to farm management.
\end{abstract}

Keywords: AMU; antibiotics; dairy cattle; DDD; biosecurity; animal welfare

\section{Introduction}

The usage of antimicrobials (AMU) to treat large animal populations in intensive livestock production is necessary to avoid animals suffering from bacterial infections and, therefore, to guarantee animal health and welfare [1], but it comes with side effects. In fact, antimicrobial use in both humans and animals leads to antimicrobial resistance (AMR) [2-5].

AMR is a global threat for both human and animal health, as it might compromise the effectiveness of infections' treatment [4,6,7]. In particular, misuse, underdosing and overuse of antimicrobials are the strongest drivers for AMR $[8,9]$. Hence, action plans on AMR were developed both at a national and international level [9-11]. At the national level, the Italian Ministry of Health promoted a plan against AMR [12], calling for antimicrobial stewardship, with the ultimate goal of providing a coordinated and sustainable strategy to address AMR nationwide. For this purpose, possible benchmarks for farm categorization according to sanitary risk, animal welfare and antimicrobial consumption have been identified [13]. This approach is also endorsed by the EU Farm to Fork strategy [14], which supports a better welfare to improve animal health and food quality and also reduce the need for antimicrobials $[15,16]$. Within this framework, biosecurity includes all procedures to prevent pathogens from entering a farm and spreading within a farm $[17,18]$. An improved biosecurity level was proven to positively impact animal health and welfare [17] and to reduce AMU in pigs [19-21] and beef cattle [22]. For dairy cattle, various studies in the 
literature investigated AMU in cows and calves [23-26]. However, only limited information is available on possible associations between AMU, biosecurity and animal welfare. There are only a few studies available on AMU in the Italian dairy sector, and they do not cover the large variety of livestock systems $[27,28]$. Therefore, the present study aimed at quantifying AMU in a geographically defined dairy cattle population in Northern Italy (Trentino Alto Adige region) for three years (2018-2020), applying two different dose-based methods. AMU associations with several management factors of biosecurity and animal welfare were also investigated.

\section{Results}

The average amount of AMU in the inspected 34 dairy farms in 2018, 2019, 2020 was, respectively, 6.48, 6.58 and 5.18 DDDAit/PCU, with a significant decrease $(p<0.001)$ in 2020 compared to both $2018(-20.1 \%)$ and $2019(-21.3 \%)$. Regarding AMU using DDDvet/PCU, the observed average values were 9.03, 8.60, 6.94 for 2018, 2019 and 2020, respectively. Penicillins and first and second generation cephalosporins were the most frequently administered antimicrobial classes, accounting for $34.85 \%$ and $13.05 \%$ of the overall AMU (Table 1). Antimicrobials classified as highest priority critically important (HPCIA), ranged between 23.52\% (in 2018) and 5.32\% (in 2020) DDDAit of the total AMU (Table 1). The use of HPCIA was reduced by 83\% from 2018 to 2020 (Table 1). HPCIA were more frequently administered via injectable products (Table 2).

Intramammary treatment was the most frequent administration route, representing $53.11 \%$ of the total AMU, followed by injectable $(45.62 \%)$, intrauterine $(1.18 \%)$ and oral administration routes $(0.09 \%)$. A significantly lower mean value of DDDAit was observed for all years in lactation compared to dry-off (Table 2), representing, respectively, 37.71\% and $62.28 \%$ of the intramammary products used.

Table 1. Percentages of defined daily doses for animals per population correction unit (DDDAit/PCU and DDDvet/PCU) administered in 2018-2020 in 34 Alpine dairy cattle farms: Antimicrobials have been grouped and classified according to WHO categorization: HPCIA: highest priority critically important antimicrobials; CIA: critically important antimicrobials; HIA: highly important antimicrobials; IA: important antimicrobials.

\begin{tabular}{|c|c|c|c|c|c|c|}
\hline & \multicolumn{3}{|c|}{ DDDAit \% } & \multicolumn{3}{|c|}{ DDDvet \% } \\
\hline & 2018 & 2019 & 2020 & 2018 & 2019 & 2020 \\
\hline HPCIA & 23.52 & 11.03 & 5.32 & 27.50 & 13.26 & 6.05 \\
\hline Cephalosporins 3rd gen. & 10.40 & 7.05 & 3.49 & 14.42 & 9.14 & 4.52 \\
\hline Cephalosporins 4th gen. & 3.76 & 0.61 & 0.00 & 5.18 & 0.21 & 0.00 \\
\hline Fluoroquinolones & 6.74 & 2.09 & 1.00 & 5.98 & 2.19 & 0.97 \\
\hline Macrolides & 2.62 & 1.29 & 0.83 & 1.92 & 1.72 & 0.56 \\
\hline Polymyxins & 0.00 & 0.00 & 0.00 & 0.01 & 0.00 & 0.00 \\
\hline CIA & 45.41 & 47.12 & 47.55 & 42.15 & 46.27 & 49.91 \\
\hline Aminoglycosides & 7.18 & 7.40 & 7.32 & 4.95 & 5.55 & 6.06 \\
\hline Ansamycin & 5.34 & 3.55 & 4.50 & 6.72 & 5.38 & 5.47 \\
\hline Penicillins & 32.90 & 36.16 & 35.72 & 30.49 & 35.35 & 38.38 \\
\hline HIA & 25.01 & 35.72 & 36.69 & 26.55 & 36.64 & 37.50 \\
\hline Amphenicols & 0.22 & 0.14 & 0.12 & 0.43 & 0.26 & 0.22 \\
\hline Cephalosporins 1st and 2nd gen. & 11.26 & 15.81 & 11.91 & 14.39 & 17.65 & 14.81 \\
\hline Lincosamides & 6.09 & 6.18 & 10.18 & 4.13 & 4.19 & 7.03 \\
\hline Sulphonamides & 3.82 & 9.74 & 9.92 & 3.62 & 9.94 & 10.18 \\
\hline Tetracyclines & 3.62 & 3.84 & 4.56 & 3.97 & 4.60 & 5.26 \\
\hline IA & 6.17 & 6.14 & 10.44 & 3.79 & 3.82 & 6.54 \\
\hline Aminocyclitols & 6.17 & 6.14 & 10.44 & 3.79 & 3.82 & 6.54 \\
\hline
\end{tabular}


Table 2. Average Defined daily doses for animals per population correction unit (DDDAit/PCU) administered in 2018-2020 in 34 Alpine dairy cattle farms: Intramammary administered antimicrobials are divided into "dry-off" and "lactation" products, while injectable, intrauterine and oral products are grouped in "not intramammary product" (not IMM). The percentage of highest priority critically important antimicrobials (HPCIA) is also reported.

\begin{tabular}{|c|c|c|c|c|c|c|c|c|c|c|}
\hline \multirow[b]{2}{*}{ Phase } & \multirow[b]{2}{*}{ n. } & \multicolumn{2}{|c|}{2018} & \multicolumn{2}{|c|}{2019} & \multicolumn{2}{|c|}{2020} & \multirow{2}{*}{ Year (Y) } & \multirow{2}{*}{ Phase (P) } & \multirow{2}{*}{$\mathbf{Y} \times \mathbf{F}$} \\
\hline & & Mean \pm sd & \% HPCIA & Mean \pm sd & \%HPCIA & Mean \pm sd & $\%$ HPCIA & & & \\
\hline dry-off & 34 & $2.21 \pm 1.21$ & $20.59 \%$ & $2.45 \pm 1.73$ & $5.88 \%$ & $1.51 \pm 1.08$ & $2.94 \%$ & & & \\
\hline lactation & 34 & $1.42 \pm 1.11$ & $35.29 \%$ & $1.21 \pm 0.96$ & $14.71 \%$ & $1.05 \pm 0.80$ & $5.88 \%$ & $<0.001$ & $<0.001$ & 0.14 \\
\hline not IMM & 34 & $3.10 \pm 1.68$ & $94.12 \%$ & $2.91 \pm 1.81$ & $76.47 \%$ & $2.74 \pm 1.96$ & $52.94 \%$ & & & \\
\hline
\end{tabular}

The analysis of management factors on AMU is shown in Table 3. Five farms performed blanket DCT (dry cow therapy) (3.36 \pm 0.22 DDDAit), while 29 farms performed selective DCT using on average 1.44 \pm 0.65 DDDAit during the dry-off period. Moreover, in the majority of the farms (i.e., 28 out of 34), microbiological tests for mastitis were routinely performed in symptomatic animals. The presence of a quarantine box, space availability, water quality, animals' cleanliness, presence of ventilation alarm and level of somatic cell count (SCC) did not exhibit any significant association with AMU. Instead, a lower DDDAit was found $(p=0.050)$ in straw/sawdust bedded cubicles compared to other materials (i.e., mattresses and concrete floor). Overall, the average biosecurity score recorded in farms was $65 \%$ (range $37-85 \%$ ), while the animal welfare average score was $77 \%$ (range 63-88\%); nonetheless, no significant correlation was found with AMU distribution. On the contrary, the quantity of daily milk produced (mean value $29.7 \pm 5.44$ ) was positively correlated with the DDDAit (Spearman's rho $=0.37, p=0.027$ ).

Table 3. Associations between defined daily doses per animal (DDDAit/PCU) and different management variables in 34 Alpine dairy cattle farms in 2020. Significance for $p<0.05$.

\begin{tabular}{|c|c|c|c|}
\hline & $\mathbf{n}$ & Mean \pm sd & $p$ Value \\
\hline \multicolumn{4}{|l|}{ Quarantine box } \\
\hline absent & 13 & $5.87 \pm 3.25$ & ns \\
\hline present & 21 & $4.95 \pm 2.19$ & \\
\hline \multicolumn{4}{|l|}{ Mortality } \\
\hline$<5 \%$ & 27 & $5.42 \pm 2.76$ & na \\
\hline$\geq 5 \%$ & 7 & $4.85 \pm 2.18$ & \\
\hline \multicolumn{4}{|l|}{ Sickbay } \\
\hline present & 31 & $5.14 \pm 2.70$ & na \\
\hline absent & 3 & $6.98 \pm 0.85$ & \\
\hline \multicolumn{4}{|l|}{ Space available (heifers) } \\
\hline$\geq 3.5 \mathrm{~m}^{2} /$ animal & 20 & $5.35 \pm 2.21$ & ns \\
\hline$<3.5 \mathrm{~m}^{2} /$ animal & 14 & $5.23 \pm 3.24$ & \\
\hline \multicolumn{4}{|l|}{ Water supply } \\
\hline$\geq 1$ drinker $/ 10$ animals & 19 & $5.08 \pm 2.06$ & ns \\
\hline$<1$ drinker / 10 animals & 15 & $5.57 \pm 3.28$ & \\
\hline \multicolumn{4}{|l|}{ Cleanliness } \\
\hline$<20 \%$ of dirty animals & 25 & $5.65 \pm 2.72$ & ns \\
\hline$\geq 20 \%$ of dirty animals & 9 & $4.32 \pm 2.23$ & \\
\hline \multicolumn{4}{|l|}{ Ventilation alarm } \\
\hline Absent & 19 & $5.43 \pm 2.98$ & ns \\
\hline present & 15 & $5.13 \pm 2.21$ & \\
\hline \multicolumn{4}{|l|}{ Access to pasture } \\
\hline No & 7 & $4.62 \pm 2.17$ & na \\
\hline Yes & 26 & $5.61 \pm 2.72$ & \\
\hline
\end{tabular}


Table 3. Cont.

\begin{tabular}{lccc}
\hline & $\mathbf{n}$ & Mean $\pm \mathbf{s d}$ & $p$ Value \\
\hline DCT & 5 & & \\
Blanket & 29 & $7.85 \pm 4.20$ & na \\
Selective & & & \\
Somatic cell count & 21 & $5.66 \pm 2.07$ & ns \\
$>150,000$ cells $/ \mathrm{mL}$ & 13 & $4.72 \pm 2.26$ & \\
$\leq 150,000$ cells/mL & & & \\
Cubicles material & 10 & $6.92 \pm 3.17$ & \\
Other & 23 & $4.74 \pm 2.07$ & \\
Straw/sawdust & & & \\
Microbiological tests for & 3 & $4.04 \pm 2.15$ & \\
mastitis & 3 & $6.03 \pm 0.61$ & \\
Absent & 28 & $5.36 \pm 2.81$ & \\
Not on a routine basis & & & \\
For all problematic cows & & & \\
sd: standard deviation; na: not applicable; ns: not significant; DCT: dry cow therapy.
\end{tabular}

sd: standard deviation; na: not applicable; ns: not significant; DCT: dry cow therapy.

\section{Discussion}

This study evaluated AMU retrospectively in a sample of holdings, mostly family-run, that we can assume are representative of Alpine dairy farming systems, characterized by small-medium size, usually with access to pasture and without a milking robot. As reported in the European Surveillance of Veterinary Antimicrobial Consumption (ESVAC) in the last decade, Italy was ranked high in Europe in terms of AMU [29]. Compared to other EU studies, this occurrence seems to be confirmed by the present data. For example, an English study [23] reported an average DDDvet of 4.60. However, comparison should be made with caution because these authors did not consider DCT. In terms of DDDAit, the dose-based values in the present study were lower than for DDDvet. DDDAit was defined for each active substance following the summary of Italian products' characteristics: this guaranteed a higher level of precision than DDDvet. Average DDDAit ranged yearly between 6.58 in 2019 and 5.18 in 2020, with a significant variability between farms (2.19-10.34). Considering a three-year timeframe can overcome outlier peak values due to exceptional circumstances and evidenced a significant decreasing trend. A previous Italian study [30] assessed AMU in dairy cattle farms using DDDAit in 2019 in north-western Italy (Lombardy region). These authors observed a similar AMU compared to the present study (4.8 DDDAit per cow / year). However, a different methodology calculation in intramammary products was applied. The number of doses was divided by the Population Correction Unit (PCU) (likewise injectable products) and not by the number of cows, as proposed by the Italian Ministry of Health for this route of administration [31]. The chosen approach can generate an apparently lower consumption estimation compared to the present study. In line with the massive decrease in sales of veterinary antibiotics in European Countries, highlighted in the 10th ESVAC report, the results of the present study show a reduction of $21.3 \%$ from 2019 to 2020. This decreasing trend had already been observed from 2007 to 2012 in the Netherlands, where dairy farms registered a $-22 \%$ reduction of AMU [32]. Conversely, Mazza et al. did not observe a significant decrement in Lombardy. Furthermore, a more prudent AMU was observed during the study period in Alpine farms, with a dramatic reduction in HPCIA $(-83 \%)$. They were eliminated in intramammary treatments in nearly all the farms. These data are encouraging, considering that in 2015 in Austria, a mean 1.14 DDDvet of HPCIA was used for lactating cows' treatments with intramammary products [33]. In US dairy farms in 2016-2017, 75\% of intramammary antimicrobials contained HPCIAs such as ceftiofur and 7\% contained cephapirin. These two active principles accounted for almost $82 \%$ of the total AMU [34]. The difference between farming system types can also play a major role. Indeed, it has been recently shown [35] that mountain farms with smaller herd sizes, which provide cows with access to pasture and limit concentrates in the diet, use less HPCIA than specialized dairy farms from lowlands. Moreover, it has been 
widely reported that higher productivity (notably higher milk yield) can be associated with a higher incidence of metabolic disorders, such as mastitis, lameness and other production diseases [36], requiring prompt veterinary intervention. Our results support this evidence, as we traced a positive correlation between milk production and AMU. In line with what is reported in the literature for dairy cattle [27,30,32,34], we found that intramammary medication is the most frequent administration route (53.11\%). Previous studies observed a frequency reaching 63\% [32] and 78\% [34]. In particular, antimicrobial treatments were reported to be more frequent during the dry-off period than during lactation. Dry-off treatments are mainly administered to prevent mastitis in the following lactation [37] but in the present study blanket DCT was performed only in 5 out of 34 farms in 2020. Indeed, most farms (28/34) performed microbiological tests for mastitis in symptomatic animals.

However, no correlation between AMU and SCC was found in the present study. A previous study demonstrated that it is possible to reduce antibiotics in dry-off without increasing somatic cells count (SCC) in the following lactation by implementing management measures to maintain good udder health [38]. For example, some risk factors for E. coli mastitis at the herd level include the bedding material and the design of cubicles [39]. The number of cubicles was classified as acceptable in all inspected farms, according to Italian welfare guidelines [13] (ranged between $90-110 \%$ of the number of cows) thus this parameter was not an object of analysis. We grouped bedding materials that needed to be frequently replaced, such as straw, sawdust or both, and we compared them to other materials (including mattresses and concrete floor). Therefore, farms that used replaceable materials had lower AMU, which can be attributed to a higher hygiene level guaranteed by a regular replacement of new material. Moreover, in the past, straw also showed a lower incidence of leg injuries in the tarsal joints [40-42], in addition to promoting better animal welfare resulting from higher comfort $[42,43]$ and the presence of manipulable material. On the other hand, other studies observed that sawdust increases the dirtiness of the hindquarters and udder [44] and, compared to straw, it increases the risk of hock skin alterations [45]. Considering these studies, straw can be assumed to be better than sawdust. However, this study does not consider that frequently dry cows are housed separately from lactating cows, and data do not distinguish eventual differences as bedding material between the two phases. Therefore, more detailed studies will be required, including the distinction between dry and lactation period and between straw, sawdust or the use of both of them. No significant correlation between AMU and biosecurity as well as animal welfare scores was observed in the present study. Additionally, no correlation between AMU, biosecurity and animal welfare was found in dairy cattle farms from Lombardy [27], which had similar scores (biosecurity range $21.41-71.56 \%$, animal welfare range $45.32-81.69 \%$ ). In the beef cattle sector, an improved level of welfare permitted lower usage of antimicrobials, but not a reduction in HPCIA [22]. On the contrary, in 61 Belgian pig farms, AMU was reduced by $52.0 \%$, without impairing the herd production performances, by adopting a series of herd-level interventions concerning biosecurity, vaccination scheme, health care, welfare and zootechnical measures [46]. Similarly, a reduction of $47 \%$ of AMU was achieved in pig farms from Belgium, France, Germany and Sweden from birth to slaughter, and farms with bigger compliance achieved a more considerable reduction [19]. However, pig farming is characterized by a general higher AMU than dairy cows (e.g., 16 DDDvet/PCU in 2017 for Tarakdjian et al., 2020 [47]), and this evidence can explain why good management practices are more likely to produce a significant effect in the former than in the latter livestock sector.

\section{Materials and Methods}

\subsection{Data Collection}

Thirty-four free-stall farms of mixed-breed dairy cows (i.e., Holstein Friesian, Brown Swiss, Simmental cows) in the Province of Trento (north-eastern Italy) were randomly selected for this study. Farms were located in the area between Garda Lake (south), Stelvio Natural Park (west), Pale di San Martino Natural Park (east) and Bolzano (north), and the altitude ranged from $400 \mathrm{~m}$ to $1700 \mathrm{~m}$. Median farm size was 89.5 animals and the 
mean was 140, representing a small-medium farm in the Italian dairy sector. In 26 of these farms, animals had access to pasture. Farms were visited in 2021; data were collected retrospectively from the farm registry from 2018 to 2020 . The biosecurity score was calculated using the Classyfarm protocol, available in Ginestreti et al. [27], and considers 15 items to compute a final score. The final score ranges from $0 \%$ to $100 \%$, where $100 \%$ is the highest level of biosecurity. Animal welfare was evaluated using Classyfarm protocol, as previously described in Ginestreti et al. [27] and Mazza et al. [30]. The score includes 70 items, 18 of which are animal-based measures (details available in Bertocchi et al. [48]). The final score ranges from 0 to $100 \%$, where $100 \%$ corresponds to the maximum level of animal welfare. The most relevant biosecurity and welfare items were also analyzed separately as qualitative variables. These items were the following: average mortality rate (higher or lower than 5\%), presence of ventilation alarm and replacement equipment, presence of sick animals' boxes, space available, presence of quarantine boxes, animal cleanliness (less or more than $20 \%$ of dirty animals), water (at least one drinker/10 animals), access to pasture, bedding material (straw and/or sawdust/others) and presence of laboratory analyses for mastitis (absent, not on a routine basis, for all problematic cows). Moreover, during the inspection, it was possible to obtain data on average yearly and daily milk production and somatic cell count (SCC) ( $>$ or $\leq 150,000$ cells $/ \mathrm{mL}$ ). Based on veterinarians' declarations, it was also possible to distinguish farms applying blanket DCT vs. selective DCT. For each farm, the average number of animals present in the farm for one year was calculated by performing three four-monthly extractions per year from the National data Registry.

\subsection{Data Analysis}

Overall, AMU per year was quantified using the Defined Daily Dose/Population Cor-rection Unit (DDDAit/PCU) method, proposed by the Italian Ministry of Health [31]. The total amount of $\mathrm{mg}$ of an active substance administered for each commercial product was divided by the dosage reported in the summary of products characteristics (SPC), which was reported in the official pharmaceutical handbook [49]. To allow a broader comparison with studies performed in other European countries, AMU was also quantified using DDDvet/PCU [50]. The European Medicines Agency (EMA) provides a standardized daily dosage for each active substance, calculated as the average concentration of various marketed products sold in the European Union (EU) [50]. All intramammary, injectable, intrauterine and oral products were analyzed. Spray AM for external use and ruminal preparations (monensin) were excluded. Oral and injectable antibiotic formulations were calculated per kilogram of animal, while intrauterine and lactating cow intramammary doses (IMM) were calculated per cow. If a range of doses was given, the mean dose was used as the DDDAit [31]. For combination products (e.g., penicillin-streptomycin), the DDDvet was estimated for the main substance, following the guidelines for the DDDvet assignment [50].

Conversely, DDDAit was estimated for both separately, according to the Italian Ministry of Health guidelines [31]. The "PCU" (Population Correction Unit), representing the entire animal biomass "at-risk" present annually in the farm, was calculated by dividing the animals into production categories and multiplying the results by the standard weight attributed to each category. According to the National Reference Centre for Animal Welfare (CreNBA) [31] guidelines, calf, heifer and cow weights were attributed as $100 \mathrm{~kg}, 300 \mathrm{~kg}$ and $600 \mathrm{~kg}$, respectively. Conversely, according to EMA guidelines for DDDvet, the weights attributed were $140 \mathrm{~kg}, 200 \mathrm{~kg}, 425 \mathrm{~kg}$ for the same previous livestock categories [50]. Antibiotics were grouped according to EMA and WHO classifications, based on their importance to human health [51,52].

\subsection{Statistical Analysis}

The effects of the phase (dry-off/lactation), year and their interaction on DDDAit distribution were assessed using a linear mixed model; the farm was considered in the model as random effect while the type of phase and year within each farm was included in the 
repeated effects part of the model, using a compound symmetry covariance structure. The Akaike Information Criterion (AIC) and the residual diagnostics were used to evaluate the model's goodness of fit. Given the model results, the evaluation of the factors collected for each farm in comparison with the DDDAit values was performed considering the year 2020 . The Wilcoxon rank-sum test was applied in the case of categorical variables, after having checked the equality of variances using Leven's robust test statistic; regarding continuous variables (i.e., daily milk production, biosecurity and animal welfare scores), the Spearman correlation coefficient was adopted. The HPCIA usage evaluation was performed after dichotomizing the variable (i.e., used at least once or not); given the observed frequencies, only the comparison between 2019 and 2020 for the injectable products was statistically analyzed, using the McNemar test. Given the massive reduction in 2020 of the HPCIAs (only 18 farms used HPCIAs at least once) and the consequent sample size reduction after stratifying by the management variables, HPCIA were not included in the risk factors analysis since the robustness of the statistical analysis would not have been satisfactory. Data analysis was conducted using software SAS v.9.4 (SAS Institute Inc., Cary, NC, USA).

\section{Conclusions}

This study evidenced a significant decrement in AMU in 34 Alpine dairy farms in 2018-2020, with particular reference to HPCIA. Penicillins and first and second generation cephalosporins were the most frequently administered antimicrobial classes and the most widely used administration route was the intramammary one, specifically during the dry-off period. Replaceable cubicle materials were associated with lower AMU, while quarantine management, available space, water supply, animals' cleanliness and somatic cell count had no significant association with AMU. Furthermore, no association between overall AW and biosecurity score was found. If confirmed by further studies, these results may suggest benchmarks for Alpine dairy farms to promote the reduction of AMU in dairy industry.

Author Contributions: Writing-original draft preparation, F.M.; statistical analysis, K.C.; data collection J.T., D.P., G.C. and S.A.; data analysis, F.M.; supervision, D.D., G.M. and G.F.; project administration, G.D.M. All authors have read and agreed to the published version of the manuscript.

Funding: Data of the present paper originate from the collaboration between IZSVe and Latte Trento s.c.a.

Institutional Review Board Statement: As this was an observational study with commercial animals, specific approval was not needed according to Directive 2010/63/EU.

Informed Consent Statement: Written informed consent was gained from each farmer prior to taking part freely to this research.

Data Availability Statement: The data presented in this study are available on request from the corresponding author. The data are not publicly available due to privacy reason.

Acknowledgments: The authors are thankful to the farmers who collaborated in this project and to Latte Trento s.c.a. for the logistic and financial support.

Conflicts of Interest: The authors declare no conflict of interest.

\section{References}

1. Bengtsson, B.; Greko, C. Antibiotic resistance-Onsequences for animal health, welfare, and food production. Ups. J. Med. Sci. 2014, 119, 96-102. [CrossRef] [PubMed]

2. Roth, N.; Käsbohrer, A.; Mayrhofer, S.; Zitz, U.; Hofacre, C.; Domig, K.J. The application of antibiotics in broiler production and the resulting antibiotic resistance in Escherichia coli: A global overview. Poult. Sci. 2019, 98, 1791-1804. [CrossRef] [PubMed]

3. EFSA (European Food Safety Authority). The European Union Summary Report on Antimicrobial Resistance in zoonotic and indicator bacteria from humans, animals and food in 2017/2018. EFSA J. 2020, 18, 6007. [CrossRef]

4. EFSA (European Food Safety Authority). Third joint inter-agency report on integrated analysis of consumption of antimicrobial agents and occurrence of antimicrobial resistance in bacteria from humans and food-Producing animals in the EU/EEA. EFSA J. 2021, 19, 6712 . 
5. Chantziaras, I.; Boyen, F.; Callens, B.; Dewulf, J. Correlation between veterinary antimicrobial use and antimicrobial resistance in food-producing animals: A report on seven countries. J. Antimicrob. Chemother. 2014, 69, 827-834. [CrossRef]

6. Laxminarayan, R.; Matsoso, P.; Pant, S.; Brower, C.; Røttingen, J.A.; Klugman, K.; Davies, S. Access to effective antimicrobials: A worldwide challenge. Lancet 2016, 387, 168-175. [CrossRef]

7. Gelband, H.; Miller-Petrie, M.; Suraj, P.; Pant, S.; Gandra, S.; Levinson, J.; Barter, D.; White, A.; Laxminarayan, R. The state of the world's antibiotics 2015. Wound Health S. Afr. 2015, 8, 30-34.

8. Clement, M.; Olabisi, M.; David, E.; Issa, M. Veterinary pharmaceuticals and antimicrobial resistance in developing countries. IntechOpen 2019. [CrossRef]

9. Mendelson, M.; Matsoso, M.P. The World Health Organization global action plan for antimicrobial resistance. SAMJ S. Afr. Med. J. 2015, 105, 325. [CrossRef]

10. WHO. Global Action Plan on Antimicrobial Resistance. Available online: https://www.who.int/publications/i/item/97892415 09763 (accessed on 1 December 2021).

11. Food and Agriculture Organization of the United Nations. The FAO Action Plan on Antimicrobial Resistance: 2016-2020; Food and Agriculture Organization of the United Nations: Rome, Italy, 2016. Available online: http://www.fao.org/3/a-i5996e.pdf (accessed on 2 December 2021).

12. Ministero della Salute. Piano Nazionale di Contrasto dell'Antimicrobico-Resistenza (PNCAR) 2017-2020; 2017. Available online: https:/ /www.salute.gov.it/imgs/C_17_pubblicazioni_2660_allegato.pdf (accessed on 20 December 2021).

13. Ministero della Salute. Programma Integrato per la Categorizzazione Degli Allevamenti. Guida Interpretativa. Available online: https:/ / www.classyfarm.it/wp-content/uploads/sites/4/2020/02/ba_check_list_bovbuf_2020-1.pdf (accessed on 24 October 2021).

14. European Commission. Farm to Fork Strategy: For a Fair, Healthy and Environmentally-Friendly Food System. Available online: https:/ / ec.europa.eu/food/horizontal-topics/farm-fork-strategy_en (accessed on 14 October 2021).

15. Isomura, R.; Matsuda, M.; Sugiura, K. An epidemiological analysis of the level of biosecurity and animal welfare on pig farms in Japan and their effect on the use of veterinary antimicrobials. J. Vet. Med. Sci. 2018, 80, 1853-1860. [CrossRef]

16. Stygar, A.H.; Chantziaras, I.; Toppari, I.; Maes, D.; Niemi, J.K. High biosecurity and welfare standards in fattening pig farms are associated with reduced antimicrobial use. Animal 2020, 14, 2178-2186. [CrossRef]

17. Dewulf, J.; Immerseel, F.V. General principles of biosecurity in animal production and veterinary medicine. In Biosecurity in Animal Production and Veterinary Medicine: From Principles to Practice, 1st ed.; Acco Uitgeverij: Leuven, Belgium, 2019 ; pp. 64-94.

18. Pandolfi, F.; Edwards, S.A.; Maes, D.; Kyriazakis, I. Connecting different data sources to assess the interconnections between biosecurity, health, welfare, and performance in commercial pig farms in Great Britain. Front. Vet. Sci. 2018, 5, 41. [CrossRef]

19. Collineau, L.; Rojo-Gimeno, C.; Leger, A.; Backhans, A.; Loesken, S.; Okholm Nielsen, E.; Postma, M.; Emanuelson, U.; Beilage, E.; Sjölund, M.; et al. Herd-specific interventions to reduce antimicrobial usage in pig production without jeopardising technical and economic performance. Prev. Vet. Med. 2017, 144, 167-178. [CrossRef]

20. Laanen, M.; Persoons, D.; Ribbens, S.; de Jong, E.; Callens, B.; Strubbe, M.; Maes, D.; Dewulf, J. Relationship between biosecurity and production/antimicrobial treatment characteristics in pig herds. Vet. J. 2013, 198, 508-512. [CrossRef]

21. Postma, M.; Backhans, A.; Collineau, L.; Loesken, S.; Sjölund, M.; Belloc, C.; Emanuelson, U.; Beilage, E.; Okholm Nielsen, E.; Stärk, K.D.C.; et al. Evaluation of the relationship between the biosecurity status, production parameters, herd characteristics and antimicrobial usage in farrow-to-finish pig production in four EU countries. Porc. Health Manag. 2016, 2, 9. [CrossRef]

22. Diana, A.; Lorenzi, V.; Penasa, M.; Magni, E.; Alborali, G.L.; Bertocchi, L.; De Marchi, M. Effect of welfare standards and biosecurity practices on antimicrobial use in beef cattle. Sci. Rep. 2020, 10, 20939. [CrossRef]

23. Hyde, R.M.; Remnant, J.G.; Bradley, A.J.; Breen, J.E.; Hudson, C.D.; Davies, P.L.; Clarke, T.; Critchell, Y.; Hylands, M.; Linton, E.; et al. Quantitative analysis of antimicrobial use on British dairy farms. Vet. Rec. 2017, 181, 683. [CrossRef]

24. Obritzhauser, W.; Trauffler, M.; Raith, J.; Kopacka, I.; Fuchs, K.; Köfer, J. Antimicrobial drug use on Austrian dairy farms with special consideration of the use of highest priority critically important antimicrobials. Berl. Münch. Tierärztl. Wochenschr. 2016, $129,185-195$.

25. Hommerich, K.; Ruddat, I.; Hartmann, M.; Werner, N.; Käsbohrer, A.; Kreienbrock, L. Monitoring antibiotic usage in german dairy and beef cattle farms-A longitudinal analysis. Front. Vet. Sci. 2019, 6, 244. [CrossRef]

26. Pereyra, V.G.; Pol, M.; Pastorino, F.; Herrero., A. Quantification of antimicrobial usage in dairy cows and preweaned calves in Argentina. Prev. Vet. Med. 2015, 122, 273-279. [CrossRef]

27. Ginestreti, J.; Lorenzi, V.; Fusi, F.; Ferrara, G.; Scali, F.; Alborali, G.L.; Bolzoni, L.; Bertocchi, L. Antimicrobial usage, animal welfare and biosecurity in 16 dairy farms in Lombardy. Large Anim. Rev. 2020, 26, 3-11.

28. Ferroni, L.; Lovito, C.; Scoccia, E.; Dalmonte, G.; Sargenti, M.; Pezzotti, G.; Maresca, C.; Forte, C.; Magistrali, C.F. Antibiotic Consumption on Dairy and Beef Cattle Farms of Central Italy Based on Paper Registers. Antibiotics 2020, 9, 273. [CrossRef]

29. EMA. Sales of Veterinary Antimicrobial Agents in Europe in 31 European Countries in 2018. Available online: https: / / www.ema.europa.eu/en/documents/report/sales-veterinary-antimicrobial-agents-31-european-countries-2018-trends-20 10-2018-tenth-esvac-report_en.pdf (accessed on 10 December 2021).

30. Mazza, F.; Scali, F.; Formenti, N.; Romeo, C.; Tonni, M.; Ventura, V.; Bertocchi, L.; Lorenzi, V.; Fusi, F.; Tolini, C.; et al. The Relationship between Animal Welfare and Antimicrobial Use in Italian Dairy Farms. Animals 2021, 11, 2575. [CrossRef] 
31. Ministero della Salute. Metodologia diCalcolo e di Valutazione del Consumo Degli Antimicrobici nel Settore Veterinario. DDD e DCD Defined Daily Dose Animal for Italy (DDDAit). Available online: https://ddd.veterinariodifiducia.it/ MetodologiaDDDConsumoAntimicrobiciV1_2.pdf (accessed on 14 October 2021).

32. Kuipers, A.; Koops, W.J.; Wemmenhove, H. Antibiotic use in dairy herds in the Netherlands from 2005 to 2012. J. Dairy Sci. 2016, 99, 1632-1648. [CrossRef]

33. Firth, C.L.; Käsbohrer, A.; Schleicher, C.; Fuchs, K.; Egger-Danner, C.; Mayerhofer, M.; Schobersberger, H.; Köfer, J.; Obritzhauser, W. Antimicrobial consumption on Austrian dairy farms: An observational study of udder disease treatments based on veterinary medication records. Peer J. 2017, 5, e4072.

34. De Campos, J.L.; Kates, A.; Steinberger, A.; Sethi, A.; Suen, G.; Shutske, J.; Safdar, N.; Goldberg, T.; Ruegg, P.L. Quantification of antimicrobial usage in adult cows and preweaned calves on 40 large Wisconsin dairy farms using dose-based and mass-based metrics. J. Dairy Sci. 2021, 104, 4727-4745. [CrossRef]

35. Zuliani, A.; Lora, I.; Brščić, M.; Rossi, A.; Piasentier, E.; Gottardo, F.; Contiero, B.; Bovolenta, S. Do Dairy Farming Systems Differ in Antimicrobial Use? Animals 2021, 10, 47. [CrossRef]

36. Oltenacu, P.A.; Broom, D.M. The impact of genetic selection for increased milk yield on the welfare of dairy cows. Anim. Welf. 2010, 19, 39-49.

37. Green, M.J.; Green, L.E.; Medley, G.F.; Schukken, Y.H.; Bradley, A.J. Influence of dry period bacterial intramammary infection on clinical mastitis in dairy cows. J. Dairy Sci. 2002, 85, 2589-2599. [CrossRef]

38. Krattley-Roodenburg, B.; Huybens, L.J.; Nielen, M.; van Werven, T. Dry period management and new high somatic cell count during the dry period in Dutch dairy herds under selective dry cow therapy. J. Dairy Sci. 2021, 104, 6975-6984. [CrossRef]

39. Schukken, Y.H.; Kremer, W.D.; Lohuis, J.A. Escherichia coli mastitis in cattle. I. Clinical diagnosis and epidemiological aspects. Tijdschr. Diergeneeskd. 1989, 114, 829-838.

40. Fulwider, W.K.; Grandin, T.; Garrick, D.J.; Engle, T.E.; Lamm, W.D.; Dalsted, N.L.; Rollin, B.E. Influence of Free-Stall Base on Tarsal Joint Lesions and Hygiene in Dairy Cows. J. Dairy Sci. 2007, 90, 3559-3566. [CrossRef] [PubMed]

41. Tucker, C.B.; Weary, D.M.; von Keyserlingk, M.A.G.; Beauchemin, K.A. Cow comfort in tie-stalls: Increased depth of shavings or straw bedding increases lying time. J. Dairy Sci. 2009, 92, 2684-2690. [CrossRef] [PubMed]

42. Wechsler, B.; Schaub, J.; Friedli, K.; Hauser, R. Behaviour and leg injuries in dairy cows kept in cubicle systems with straw bedding or soft lying mats. Appl. Anim. Behav. Sci. 2000, 69, 189-197. [CrossRef]

43. Manninen, E.; de Passillé, A.M.; Rushen, J.; Norring, M.; Saloniemi, H. Preferences of dairy cows kept in unheated buildings for different kind of cubicle flooring. Appl. Anim. Behav. Sci. 2002, 75, 281-292. [CrossRef]

44. Lardy, R.; Des Roches, A.D.B.; Capdeville, J.; Bastien, R.; Mounier, L.; Veissier, I. Refinement of international recommendations for cubicles, based on the identification of associations between cubicle characteristics and dairy cow welfare measures. J. Dairy Sci. 2021, 104, 2164-2184. [CrossRef]

45. Potterton, S.L.; Green, M.J.; Harris, J.; Millar, K.M.; Whay, H.R.; Huxley, J.N. Risk factors associated with hair loss, ulceration, and swelling at the hock in freestall-housed UK dairy herds. J. Dairy Sci. 2011, 94, 2952-2963. [CrossRef]

46. Postma, M.; Vanderhaeghen, W.; Sarrazin, S.; Maes, D.; Dewulf, J. Reducing antimicrobial usage in pig production without jeopardizing production parameters. Zoonoses Public Health 2017, 64, 63-74. [CrossRef]

47. Tarakdjian, J.; Capello, K.; Pasqualin, D.; Santini, A.; Cunial, G.; Scollo, A.; Mannelli, A.; Tomao, P.; Vonesch, N.; Di Martino, G. Antimicrobial use on Italian pig farms and its relationship with husbandry practices. Animals 2020, 10, 417. [CrossRef]

48. Bertocchi, L.; Fusi, F.; Angelucci, A.; Bolzoni, L.; Pongolini, S.; Strano, R.M.; Ginestreti, J.; Riuzzi, G.; Moroni, P.; Lorenzi, V. Characterization of hazards, welfare promoters and animal-based measures for the welfare assessment of dairy cows: Elicitation of expert opinion. Prev. Vet. Med. 2018, 150, 8-18. [CrossRef]

49. Ministero della Salute. Sistema Informativo Veterinario. Available online: https:/ / www.vetinfo.it (accessed on 16 November 2021).

50. European Medicines Agency (EMA). Defined Daily Doses for Animals (DDDvet) and Defined Course Doses for Animals (DCDvet): European Surveillance of Veterinary Antimicrobial Consumption (ESVAC). Available online: http://www.ema.europa. eu/docs/en_GB/document_lbrary/Other/2016/04/WC500205410.pdf.45 (accessed on 6 December 2021).

51. European Medicines Agency (EMA). Categorisation of Antibiotics Used in Animals Promotes Responsible Use to Protect Public And Animal Health. Available online: https://www.ema.europa.eu/en/news/categorisation-antibioticsused-animals-promotesresponsible-use-protect-public-animal-health (accessed on 9 November 2021).

52. WHO. Critically Important Antimicrobials for Human Medicine, 6th ed.; WHO: Geneva, Switzerland, 2019. Available online: https:/ / apps.who.int/iris/bitstream/handle/10665/312266/9789241515528-eng.pdf (accessed on 6 December 2021). 